\title{
骨髄腫の脊椎病変に対する治療経験
}

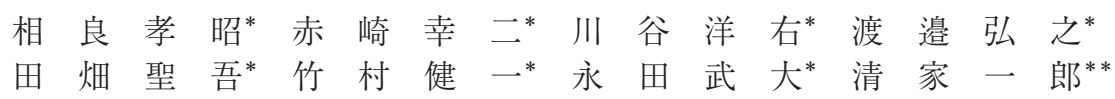

\section{Treatment for Myeloma of the Spinal Lesions}

Taka-aki Sagara*, Koji Akasaki*, Yosuke Kawatani*, Hiroyuki Watanabe*, Shogo Tahata*, Kenichi Takemura*, Takehiro Nagata*, and Ichiro Seike**

\begin{abstract}
当科にて 2001 年以降に診断・治療を行った骨髄腫症例 8 例を検討した。入院時年齢は平均 64 歳（35 $\sim 78$ 歳), 男性 5 例, 女性 3 例であった。内訳は多発性骨髄腫 7 例, 孤立性骨髄腫 1 例で, 手術治療を行っ たのは，多発性骨髄腫 4 例，孤立性骨髄腫 1 例であった。手術レべルは 4 例が胸椎， 1 例は腰椎であり， 胸椎は椎弓切除十後方固定術, 腰椎は椎弓切除が施行されていた，術前 Frankel B の症例は術後も神経学 的回復は無く ADL 回復は得られなかった。 8 例中 6 例は診断確定後 3 ケ月 3 年 10 ケ月で死亡した。骨 髄腫は血液悪性疾患のため病態が複雑であり，予後予測は困難であった。しかし多発性骨髄腫に対する新 薬治療により今後患者の生命予後が改善することが予想され，患者の ADL 改善のため今後更に整形外科 医と内科医の連携が重要になると考えられた.
\end{abstract}

We experienced eight cases of myeloma with spinal lesion from 2001. The patients consisted of five males and three females with mean age of 64 years (range : 35 to 78 years). Seven patients had multiple myeloma and a patient had solitary myeloma. Five patients were obliged to undergo operative therapy because of pain and muscle weakness of the lower extremity, but two patients did not recover from Frankel B grade. The prognosis of myeloma patients with vertebral lesions seems to be very difficult to predict.

Cooperation between physicians and orthopedic surgeons will become increasingly important.

Key words : myeloma（骨髄腫）， spinal lesion（脊椎病変）, surgical treatment（手術的治療）

\section{は じめに}

多発性骨髄腫は終末分化 B 細胞に由来する治癒が 極めて困難な血液悪性疾患である，本疾患の骨病変は 臟器障害のひとつとして定義されており, 症候性骨髄 腫として治療対象となる4. 骨髄腫の脊椎病変症例に 遭遇することは稀ではないが，治療方針の決定に難渋 することも多い．当科で骨髄腫の脊椎病変に対して診 断と治療を行った 8 例を経験したので, 検討を加えて 報告する。

\section{対}

\section{象}

対象にした骨髄腫症例は当科に抒いて 2001 年以降
に脊椎手術を施行した症例または腰背部痛の精査で当 科に入院して初めて骨髄腫と診断された 8 例である. 女性 3 例, 男性 5 例, 入院時平均年齢は 64 歳, 8 例 中 7 例が多発性骨髄腫，1例が孤立性骨髄腫であっ た. 8 例中 5 例に手術を施行した。

\section{結果}

症例の一覧を表 1 に提示した。初発症状は症例 1 を 除きいずれも腰背部痛であった。症例 2 及び症例 4 は 内科にて診断治療中に麻痺が発生し当科にて手術治療 を行ったが，その他の 6 例中 4 例は下肢麻疩を併発し て当科に初診入院, 2 例が腰背部痛の精查で当科初診 入院していた，診断は症例 3 が孤立性骨髄腫で，その

\footnotetext{
* 熊本市民病院整形外科 Department of Orthopedic Surgery, Kumamoto City Hospital, Kumamoto, Japan

** 熊本市民病院リウマチ科 Department of Rheumatology, Kumamoto City Hospital, Kumamoto, Japan
} 
表 1 症例一覧

\begin{tabular}{|c|c|c|c|c|c|c|}
\hline 症例 & 年齢 & 性別 & 麻痺障害高位 & 初発症状 & 初療の流れ & 診断 \\
\hline (1) & 58 & 男 & Th 3 & 両下肢麻瘒, しびれ & $\begin{array}{l}\text { 発症後 } 2 \text { 週で歩行不能, } \\
\text { 整形外科入院手術 }\end{array}$ & $\mathrm{MM}$ \\
\hline (2) & 61 & 男 & L 3 & 腰背部痛 & $\begin{array}{l}\text { 発症後 } 4 \text { ケ月で内科治療開始, } \\
\text { 診断 } 2 \text { 年後に排尿障害で手術 }\end{array}$ & $\mathrm{MM}$ \\
\hline (3) & 35 & 男 & Th 4 & 背部痛, 両下肢麻痺 & $\begin{array}{l}\text { 発症後 } 3 \text { カ月で } \\
\text { 整形外科入院手術 }\end{array}$ & $\mathrm{SM}$ \\
\hline (4) & 65 & 男 & Th 10 & 腰痛 & $\begin{array}{l}\text { 発症後 } 1 \text { 力月で内科治療開始 } \\
\text { 診断 } 11 \text { 力月後に下肢麻疩で手術 }\end{array}$ & $\mathrm{MM}$ \\
\hline (5) & 59 & 男 & Th 2 & 背部痛, 両下肢麻痺 & $\begin{array}{l}\text { 発症後 } 1 \text { カ月で } \\
\text { 整形外科入院手術 }\end{array}$ & $\mathrm{MM}$ \\
\hline (6) & 78 & 女 & L 1, L 5 & $\begin{array}{c}\text { 腰背部痛, 両下肢 } \\
\text { 麻痺 }\end{array}$ & $\begin{array}{l}\text { 発症後 } 1 \text { カ月で整形外科入院 } \\
\text { 診断のみで血液内科へ転科 }\end{array}$ & $\mathrm{MM}$ \\
\hline (7) & 55 & 女 & 麻瘴無し & 腰痛 & $\begin{array}{l}\text { 発症後 } 4 \text { ヶ月で整形外科入院 } \\
\text { 診断のみで血液内科転科 }\end{array}$ & MM \\
\hline (8) & 56 & 女 & 麻痺無し & 左背部痛 & $\begin{array}{l}\text { 発症 } 1 \text { カ月で整形外科入院 } \\
\text { 診断のみで血液内科へ転科 }\end{array}$ & $\mathrm{MM}$ \\
\hline
\end{tabular}

$\mathrm{MM}$ : 多発性骨髄腫, S M : 孤立性骨髄腫

表 2 治療結果

\begin{tabular}{|c|c|c|c|c|c|}
\hline 症例 & 手術 & 放射線治療 & $\begin{array}{l}\text { 除痛効果／ } \\
\text { 麻痺改善効果 }\end{array}$ & $\begin{array}{c}\text { 化学療法/ } \\
\text { 造血幹細胞移植法 }\end{array}$ & 生命予後 \\
\hline (1) & $\begin{array}{c}\text { Th } 3 \text { 椎弓切除 } \\
\text { 後方固定術 }\end{array}$ & - & $+/-$ & $-/-$ & 死亡（術後 3 ケ月） \\
\hline (2) & L 2 椎弓切除 & + & $+/+$ & $+/+$ & $\begin{array}{c}\text { 死亡（診断後 } 3 \text { 年 } 7 \text { ケ月 } \\
\text { 手術後 } 1 \text { 年 } 8 \text { カ月) }\end{array}$ \\
\hline (3) & $\begin{array}{l}\text { Th } 4 \text { 椎弓切除 } \\
\text { 後方固定術 }\end{array}$ & + & $+/+$ & $->-$ & 生存中（術後 3 年 3 力月） \\
\hline (4) & $\begin{array}{c}\text { Th } 10 \text { 椎弓切除 } \\
\text { 後方固定術 }\end{array}$ & - & $-/-$ & $+/-$ & $\begin{array}{r}\text { 死亡（診断後 } 1 \text { 年 } 2 \text { ケ月 } \\
\text { 手術後 } 3 \text { 力月) }\end{array}$ \\
\hline (5) & $\begin{array}{l}\text { Th 1-3 椎弓切除 } \\
\text { 後方固定術 }\end{array}$ & - & $+/+$ & $+\angle-$ & 生存中（術後 10 力月） \\
\hline (6) & $(-)$ & + & $+/-$ & $+/-$ & 死亡（診断後 4 ケ月） \\
\hline (7) & $(-)$ & + & $+／$ 麻痺無し & $+/+$ & 死亡（診断後 2 年 11 ケ月) \\
\hline (8) & $(-)$ & + & + ／麻痺無し & $+/-$ & 死亡（診断後 3 年 10 ケ月) \\
\hline
\end{tabular}

他は全例多発性骨髄腫であった。手術レベルは胸椎レ ベルが 4 例, 腰椎レベルが 1 例で, 胸椎病変に対して 椎弓切除+後方固定術, 腰椎では椎弓切除のみ施行し た. 放射線治療は保存的治療群では全例, 手術群で 2 例施行されていた. 術前 Frankel B の症例 1 及び症例
4 は術後も神経学的な回復は得られず, 自立歩行不能 で Performance Status は 4 の状態であった。内科的 治療として, 多発性骨髄腫の 7 例中 6 例は化学療法が 施行されていた。また自家末梢骨幹細胞移植術は 2 例 施行されていた。現在孤立性骨髄腫症例と多発性骨髄 
腫の 1 例は存命しているが，6例は診断確定後 3 力月 から 3 年 10 カ月で死亡した（表 2).

症例

症例 $4: 65$ 歳男性. 腰痛にて発症し血液内科で化学
療法が施行されていたが下肢麻痺が出現し，MRIで 第 10 胸椎レベルでの髄外腫瘤による春髄圧迫を認め た（図 1). 第 10 胸椎椎弓切除及び後方固定術を施行 するも術前 Frankel B であった下肢麻痺は改善無くで ADL 向上は得られなかった（図 2). その後徐々に全
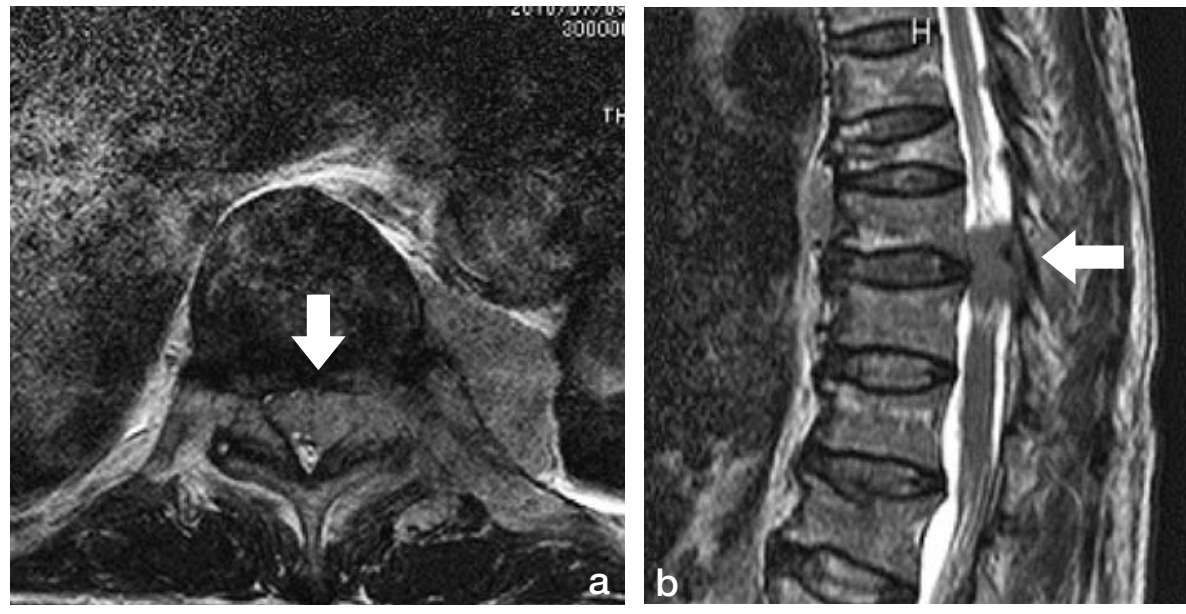

図 1 症例 4 MRI 像

$\mathrm{a}$ : 横断像 $(\Rightarrow$ 腫瘍 $) \quad \mathrm{b}$ : 矢状断像 $(\Rightarrow$ 腫瘍 $)$

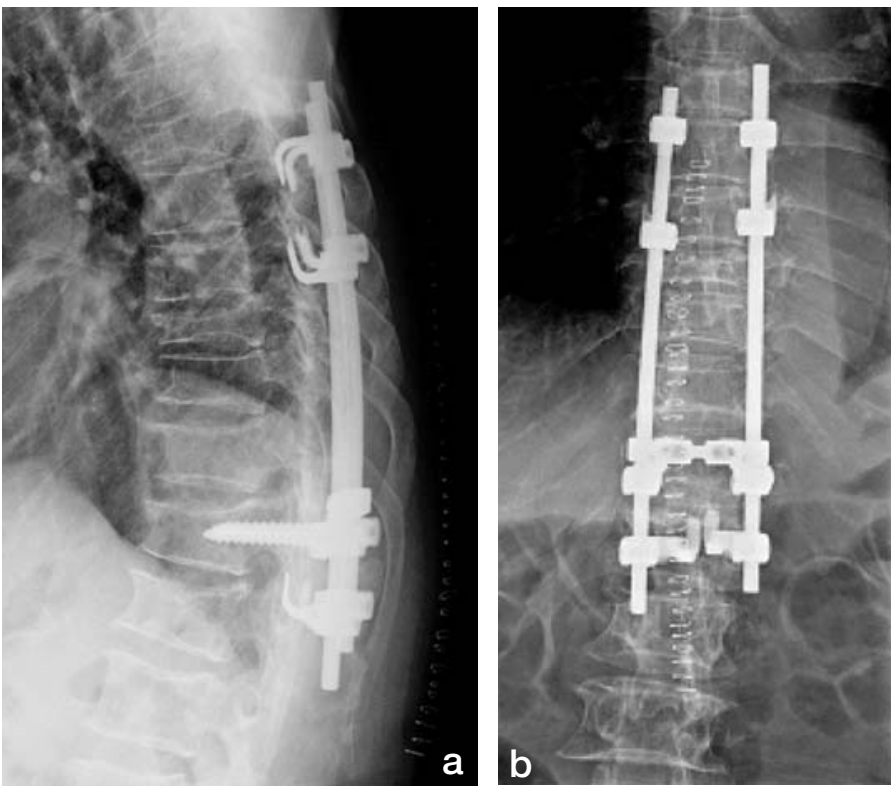

図 2 症例 4 手術後 X 線像 $\mathrm{a}$ : 側面像 $\mathrm{b}$ : 正面像 

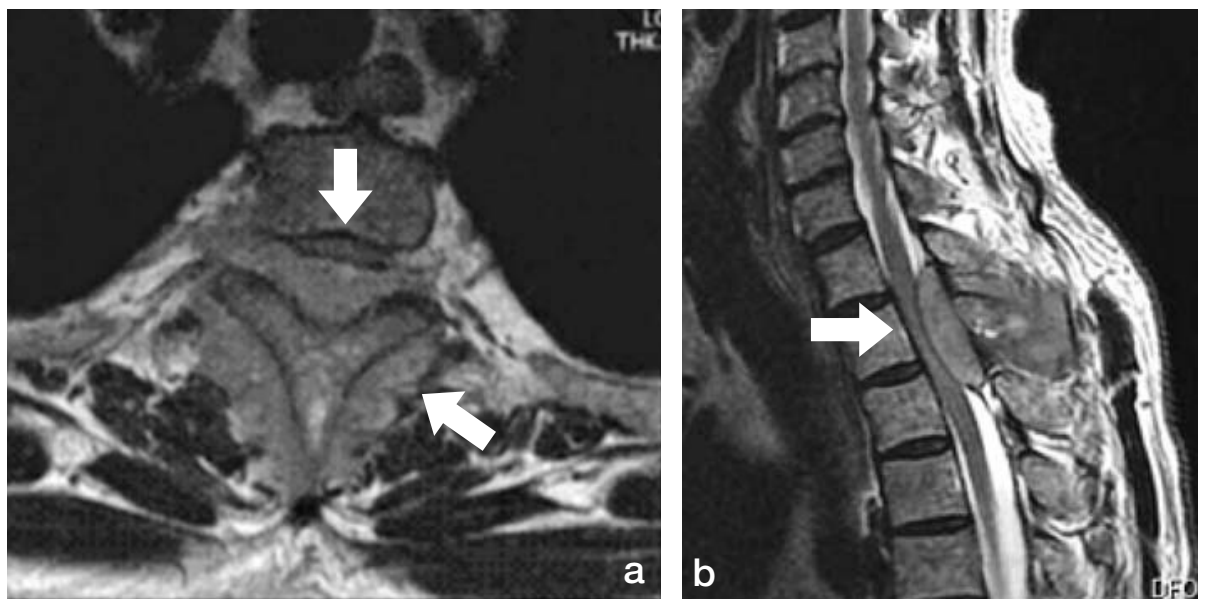

図 3 症例 5 MRI 像

$\mathrm{a}:$ 横断像 $(\Rightarrow$ 腫瘍 $) \quad \mathrm{b}$ : 矢状断像 $(\Rightarrow$ 腫瘍 $)$

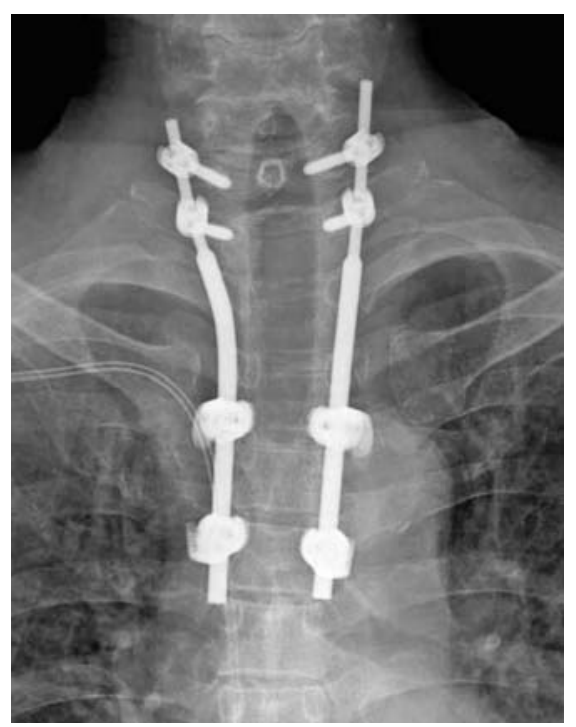

図 4 症例 5 手術後 X 線像 正面像

身状態が悪化して手術 3 カ月後に死亡した.

症例 $5: 59$ 歳男性. 背部痛で発症し 1 力月後に Frankel C の下肢麻痺が出現した。当科受診し第 1 胸 椎から第 3 胸椎レベルで硬膜外腫瘍を認め（図 3), 緊急で胸椎椎弓切除及び後方固定術を施行した（図 4). 術後病理組織で形質細胞増殖をみとめ, 骨髄腫と 診断された。神経麻痺は Frankel B に回復し, 歩行可
能となった。内科にて化学療法されるも結腸穿孔が発 生し腹部手術も受けている. 術後 10 力月の現在, 存 命中である.

考察

International myeloma working group の診断基準 ${ }^{4)}$ により治療が必要な骨髄腫は明確に示されている。す なわち多発性骨髄腫の臓器障害を CARBO とし, こ の臓器障害のある骨髄腫を治療が必要な症候性骨髄腫 とした ${ }^{3)}$. 骨病変は本疾患の蔵器障害として定義され ており骨転移の概念とは異なる。

多発性骨髄腫は平均して数年で亡くなられる予後不 良の疾患であるが, 近年の造血幹細胞移植法の定着や 新規薬剤の併用療法などでその生命予後は確実に延長 している ${ }^{6)}$. しかし当院の多発性骨髄腫症例は種々の 合併症を併発した予後不良例が多く, 手術群（5例） で診断後平均 20 力月, 手術後平均 9 力月, 非手術群 (3 例) では診断後平均 28 か月で死亡していた。多発 性骨髄腫の脊椎病変に対する手術は除圧と脊柱再建に よる ADLの改善が目的である が，転移性脊椎腫瘍 の手術適応の判断となる予後予測を徳橋法 ${ }^{8)}$ で検討し たところ本症例では 7 例中 3 例しか一致せず，全身性 の血液疾患である多発性骨髄腫の手術適応及び方法 を判断することは現状では困難と思われた。本症例の 検討からは少なくとも Frankel B P Performance status 4 の患者では手術適応は無いのではないかと考 
えられる。

多発性骨髄腫の確立されている標準的治療は, 65 歳未満では状態が良ければ造血幹細胞移植療法を適応 し寛解導入をめざす治療 ${ }^{5)}$ であり，65 歳以上の初発例 には MP（メルファラン+プレドニゾロン）療法を行 うのが基本であった などの新規薬剤が再発難治例に投薬できるようにな $り^{6)}$, 更に 2011 年から初期治療にも適応となったプロ テアソーム阻害剂であるボルテゾミブは強力な抗腫瘍 効果を有する ${ }^{19)}$ とともに，骨新生促進効果にもすぐ れており骨病変の改善も期待されている ${ }^{3)}$. 今後更に 多発性骨髄腫の生命予後が大きく改善し患者のライフ スパンが伸びることが予想されるので，治療としての 手術的介入の適応やタイミングについて今後更に整形 外科医と腫瘍内科医が密接に連携することが重要であ る と考える.

\section{ま と め}

当科にて手術を施行した多発性骨髄腫 4 例，孤立性 骨髄腫 1 例及び当科に腰背部痛の精査で入院し多発性 骨髄腫と診断された 3 例，計 8 例について報告した。 手術は胸椎が 4 例, 腰椎が 1 例で, 胸椎は全例椎弓切 除十後方固定術を施行していた。術前 Frankel B level の症例は術後も歩行不能で, ADLの改善は得られな かった。多発性骨髄腫に対する新薬治療により生命予
後が将来大きく改善することが期待されており，患者 の ADL 改善のため今後更に整形外科医と内科医の連 携が重要になると考えられた。

\section{参 考 文 献}

1）張 高明: 多発性骨髄腫の治療. 日経メディカル Cancer Review 2010，6:34-41， 2010.

2) 長谷斉ら：骨髄腫. 脊椎脊髄, $16: 1213-1219$, 2003.

3）稲垣 淳, 飯田真介：多発性骨髄腫に対する個別化治 療の試みと実際。臨床腫瘍プラクティス, $7: 78-83$, 2011.

4) International Myeloma Working Group:Criteria for the classification of monoclonal gammopathies, multiple myeloma and related disorders : a report of the International Myeloma Working Group. Br. J. Haematol., 121 : 749-757, 2003.

5）和泉 透: 多発性骨髄腫に対する造血幹細胞移植. 最 新医学, 64：117-122, 2009.

6）三輪哲義：多発性骨髄腫. Medicina, 47 : 2176-2182, 2010.

7) Scharschmidt, T. J., et al. : Multiple myeloma : diagnosis and orthopaedic implications. J. Am. Acad. Orthop. Surg., 19: 410-419, 2011.

8）徳橋泰明ら：転移性脊椎腫瘍の手術適応と術式選択. 脊椎脊髄，16：673-680，2003.

9）矢野寛樹，飯田真介：ボルテゾミブ療法. Current Therapy 2010, 28:60-64, 2010. 